\title{
ПРАВОВЕ РЕГУЛЮВАННЯ ВИЗНАЧЕННЯ СТАТІ В КОНТЕКСТІ ВПРОВАДЖЕННЯ ПОЛІТИКИ ГЕНДЕРНОї РІВНОСТІ В УКРАÏHI
}

\author{
ХОБОР Романа Богданівна - кандидат юридичних наук, старший викладач \\ кафедри медичного права, факультет післядипломної освіти Львівського \\ національного медичного університету імені Данила Галицького (м. Львів, \\ Україна)
}

ORCID: https://orcid.org/0000-0001-8674-063X

УДК: 349.2

DOI

В статье обсуждается ряд вопросов, связанньих с главнълм ее сюжетом - правовълм регулированием определения пола. Ведущим объектом критики въгтупает тезис, в соответствии с которьм половая принадлежность является не бинарной оппозиичей, а представляет собой спектр. Таким образом представители гендернъих исследований пвттаются продемонстрировать, что небинарность гендера укоренена в небинарности пола. Именно в этом кроется uх пристальное внимание к интерсексам, ведь последних предлагают понимать как свидетельство того, ито пол (как и гендер) является спектром. Отмечается ошибочность подобной понятийной трансплантации, поскольку пол на самом деле определяется не наличием гениталий, их размером и/или функииональностью, а гаметами, которьие бълвают только двух видов либо женские, или мужские. Автор приходит к въгводу, ито использование понятия «гендер»на национальньхх территориях свидетельствует о признании государством того обстоятельства, что большинство различий между мужчинами и женшинами имеют скорее сочиальньий, чем биологический характер, а поэтому для формирования идентичности личности гендер имеет более важное значение, чем пол. При таких условиях половая диббберенциация в отечественном законодательстве выллядит как атавизм. Делается въгвод о необходимости унибикации использования понятий «пол» $и$ «гендер». При этом, однако, следует четко представлять, в каких случаях дибберенииация должна носить половой, а в каких - гендерное содержание.

Ключевъге слова: пол, гендер, половая диббберенииация, дисбория, гендернъие студии.

\section{Вступ}

Однією з рис, які визначають нинішню епоху, є, за влучним вираженням Г. Кубі, глобалізація сексуальної революції [1, с. 70]. Становлення в XX столітті психології та споріднених наук, на кшталт сексології, спричинили переосмислення статевого поділу суспільства. Якщо раніше статева диференціація уявлялася природною та, у своїй основі, біологічною, то тепер іiі повсюдно інтерпретують у суспільно-психологічному ключі, у результаті чого на порядку денному світової праволюдинної політики стоїть забезпечення вже не статевой, а гендерної рівності, про що Об’єднані Нації заявили ще у своїх Цілях тисячоліття [2].

Складно сказати, що вплинуло на цю загальносвітову тенденцію більше, дискредитація біології (після химерних намагань використати ії положення для обгрунтування расової нерівності, антисемітизму та нацизму) [3] чи все ж таки утвердження антропологічного світосприйняття, однак, так чи так, їхній кумулятивний ефект призвів до того, що соціальній природі чоловіків та жінок почали надавати істотно більшого значення, ніж біологічній.

Пропонована вашій увазі розвідка має на меті висвітлити наявний стан і тенденції співвідношення в національному правопорядку між поняттями статі та гендеру. Робити ми це будемо в контексті аналізу правового регулювання порядку визначення статі. Цей, можливо, дещо несподіваний (принаймні з точки зору відсутності попередніх до- 
сліджень 3 аналогічного предмета) ракурс дасть можливість краще усвідомити плетеницю зв’ язків між відповідними поняттями, а також забезпечить вихідними міркуваннями для прогнозування перспектив реалізації в Україні політики гендерної рівності.

До слова, для постановки озвучених питань на вітчизняних теренах 6 вельми вдалий привід: 3-поміж подій у галузі прав людини липень 2021 року відзначився новиною про те, що Сполучені Штати оголосили запровадження у найближчому майбутньому «гендеру Х» як засобу офіційної ідентифікації фізичних осіб [4]. Ця подія, як видається, так чи інакше справить вплив на формування та реалізацію гендерної політики по обидва боки Атлантичного океану, а іiї проєкції на вітчизняний правопорядок, безумовно, заслуговують на увагу вже зараз.

Насамкінець, актуальність пропонованої теми зумовлюється спершу нашумілим, а тепер, як видається, дещо «відшумілим» підписанням Україною Конвенції Ради Европи про запобігання насильству стосовно жінок і домашньому насильству та боротьбу з цими явищами (більше відомої як Стамбульська конвенція) ще в далекому листопаді 2011 року. Зволікання з ратифікацією зумовлені, вочевидь, браком політичної волі, віддзеркаленням якого $є$ відсутність необхідної законодавчої ініціативи. Між тим, Україна немов завмерла між двома альтернативами, що проєктуються на геополітичний простір або у формі своєрідного сусідства з Туреччиною (яка 3 липня цього року вийшла зі Стамбульської конвенції), або 3 країнами $\mathrm{EC}$, які підписали і ратифікували останню [5]. Ці питання мають особливо актуальний характер з огляду на ту обставину, що Конвенція є чи не найсильнішим інструментом забезпечення стандартів гендерної рівності не лише в національних правових системах держав-учасниць Ради Европи, але й за межами останньої.

Пропоноване дослідження носить міждисциплінарний характер. У ньому використовуються знання біології, генетики i медицини у їхньому зв'язку із правовим регулюванням.

\section{Структура дослідження}

Ми почнемо 3 викладення понятійного апарату, після чого перейдемо до аналізу правового регулювання в аспекті визначення статі людини та завершимо міркуваннями про співвідношення статі і гендеру за національним законодавством, а також перспектив розвитку цього співвідношення.

\section{Понятійний апарат}

Як відомо, нині відбувається імплементація у законодавство України елементів політки гендерної рівності, що опосередковується, зокрема, усе більшим поширенням тут терміно-поняття «гендер». Використовується воно задля утвердження заборони гендерної дискримінації та інших стандартів гендерної рівності на вітчизняних теренах. Як ми продемонструємо нижче, у національному законодавстві навряд чи знайдеться інша пара понять, яку $б$ використовували настільки непослідовно, як «стать» i «гендер», а відтак існує нагальна потреба визначити і розмежувати останні з міркувань забезпечення законодавчої економії.

Стать організму є важливою фенотиповою характеристикою, яка поєднує в собі ряд морфологічних і функціональних властивостей, що забезпечують відтворення нащадків і передачу їм спадкової інформації $[6, \text { с. } 717]^{1}$. «Стать у людини - це ознака генетично детермінована, успадковується за законами Менделя, про що свідчить рівне співвідношення статей у кожному наступному поколінні», - пише колектив викладачів Вінницького університету [6, с. 718$]^{2}$.

Зазвичай вказують, що стать людини визначається комбінацією 46 ХХ та XY хромосом батьків ${ }^{3}$. Попри те, що подібне пояснен-

\footnotetext{
${ }^{1}$ Шевчук T.I. Молекулярно-генетичні механізми і рівні визначення статі у людини та їх порушенн / Хлєстова С.С., Горбатюк С.М., Васенко Т.Б., Спрут О.В. Вісник Вінницького національного медичного університету, 2019, Т. 23, №4, с. 717

${ }^{2}$ Шевчук Т.I. Молекулярно-генетичні механізми і рівні визначення статі у людини та їх порушенн / Хлєстова С.С., Горбатюк С.М., Васенко Т.Б., Спрут О.В. Вісник Вінницького національного медичного університету, 2019, Т. 23, №4, с. 717

3 Третім варіантом поєднання є т.зв. мозаїцизм, коли одні клітини мають хромосоми типу XXY, a інші XY.
} 
ня вважається прийнятним, воно, на нашу скромну думку, лише розкриває генетичний процес вибору статі.

Власне відмінність між протилежними статями пояснюе те, які саме гамети виробляє організм [7, с. 14-19]. У людини зустрічаються лише два різновиди гамет, жіночі і чоловічі: яйцеклітина і сперматозоїд. Саме звідси бундаментально випливае диферениіація на статі, яка опосередковується в суспільних відносинах через гендерні ролі. Поділ на статі має бінарний характер.

I хоча зазвичай давати визначення від протилежного справа невдячна, з гендером такий підхід поцілює в саму суть: передусім треба знати, що гендер це не стать. Але, при цьому ж, уявити собі гендер без статі неможливо. Подібний тип зв'язків можна схарактеризувати як взаємний або діалектичний.

Пошуки офіційного (чи офіціозного) тлумачення поняття гендеру ведуть врешті до низки джерел м'якого права, прийнятих під егідою ООН. Так, у доповіді Генерального секретаря ООН від 3 вересня 1998 р. «Запровадження гендерної перспективи в роботу договірних органів Об'єднаних Націй» термін «гендер» означає соціально конструйовані ролі жінок та чоловіків, які приписують останнім на підставі статі, у публічному або особистому житті. Термін «стать» означає біологічні та фізіологічні характеристики жінок та чоловіків [8, с. 5].

«Гендерні ролі, - зазначав Генеральний секретар ООН, - зумовлюються конкретним соціально-економічним, політичним та культурним контекстами; на них також впливають інші чинники, зокрема вік, раса, клас та етнічна приналежність» [8, с. 6]. Різноманіття гендерних ролей, які опановуються в конкретних суспільствах, можна спостерігати як у межах одного суспільства, так і в порівнянні з іншими.

Згідно із поясненням Спеціального радника Генерального секретаря 3 гендерних питань, гендер означає соціальні риси та можливості, які асоціюються 3 жінками та чоловіками та взаєминами між жінками, чоловіками, хлопчиками і дівчатками. Ці риси, можливості і взаємини є соціальними конструктами, які опановуються в процесі соціалізації. Вони зумовлюються контекстом, ча- сом, можуть змінюватись. Гендер визначає, чого очікувати, що дозволено і що цінується в жінках та чоловіках, а також яка «питома вага» відповідальності лежить на перших i других. У більшості суспільств $є$ відмінності й нерівності між жінками та чоловіками, що виявляється в їхніх різних

- обов'язках та відповідальності;

- ролях;

- власності на ключові ресурси;

- можливостях для прийняття рішень [9].

Отже, гендер - ие соиіально сконструйована стать, яка опосередковується у суспільних відносинах через обов'язки, відповідальність, ролі i фактичні можливості жінок та чоловіків.

Ще одним поняттям, що тісно пов'язане зі вже розглянутими вище, є гендерна ідентичність. Згідно з Джок'якартськими принципами остання визначається як глибоке усвідомлення тією чи іншою особою внутрішніх та індивідуальних особливостей гендерної приналежності, яка може як збігатися, так і не збігатися зі статтю за народженням, включаючи індивідуальне відчуття свого тіла (при наявності вільної волі може супроводжуватися зміною зовнішності або фізіологічних функцій медичними, хірургічними або іншими засобами) та інші прояви, такі як одяг, мова і особливості поведінки [10].

Гендерна ідентичність може як збігатись, так і не збігатись зі статтю. Незбіг носить назву «транссексуалізм» і кваліфікується за Міжнародною класифікацією хвороб десятого перегляду [12] та законодавством України [13] ${ }^{4}$ в якості психічного і поведінкового розладу. Щоправда, такий підхід зазнає змін уже з наступного року, з набуттям чинності Міжнародної класифікації хвороб одинадцятого перегляду ${ }^{5}$.

Для розуміння статі і гендеру важливого значення набуває уявлення про їхню тяглість: гендер - це не бінарна опозиція, а тяглість - тобто множина, поєднана в єдине

\footnotetext{
${ }^{4}$ Медико-біологічні та соціально-психологічні показання для зміни (корекції) статевої належності https://zakon.rada.gov.ua/laws/show/z1589-16\#n17 5 Rodríguez MF, Granda MM, González V. Gender Incongruence is No Longer a Mental Disorder. J Mental Health \& Clin Psychology (2018) 2(5): 6-8
} 
ціле низкою сімейних подібностей. Як зазначають дослідники, гендерна теорія стверджує про те, що «біологічна стать як чоловіка, так і жінки не має значення для людської ідентичності, а є лиш «диктатурою природи» над вільним самовизначенням людини, від якої треба визволитися» [1, с. 68]. Гендер, відповідно, є не дихотомією, а континуумом чи тяглістю. На формування гендеру справляють вплив такі фактори як стать, сексуальна орієнтація, наявність чи відсутність гендерної дисфорії тощо [14]. Через уведення поняття «гендер» у національні джерела феміністки намагаються «розчинити» в народних масах «токсичну мускульність» [15, с. 715-718], яка, на їхню думку, є головною причиною дискримінації й утиску жінок у всьому світі.

«Передбачається, що все соціальне біологічно основане і тільки як таке вважається природним і нормальним, - пишуть О. Здравомислова та А. Темкіна. - Таким чином закріплюється позаісторізм і есенціалізм (сутнісна незмінність) сформованих відносин між статями і взагалі соціальними групами, які відрізняються за біологічними ознаками». «Богу - богове, людині - людське, негру - рабство, білому - президентське крісло. Природа людини, з цієї точки зору, двоїста - усе на світі ділиться на «чоловіче» $\mathrm{i}$ «жіноче», - саркастично підсумовують авторки [16, с. 111]. Саме тому вважають, що рівність чоловіків і жінок можлива лише в небінарному суспільстві.

Однак сучасний рух за гендерну рівність оголосив війну іще одній бінарній опозиції поділу на статі. На обгрунтування тези, що стать $є$ множиною, зазвичай пропонують обмірковувати іï за аналогією із гендером [7,c. 15, 16, 20-22]. Що цікаво, як доказ, що «жінка-чоловік» не є бінарною опозицією, представники гендерних студій наводять приклади осіб, які страждають на порушення статевої диференціації. Так авторитетний колектив Хелслайн Едіторіел Тім зазначає, що інтерсексуальність теж є спектром, полюсами якого є чоловік, з одного боку, та жінка - $з$ іншого [17].

Можна схарактеризувати означений щойно підхід як спробу трансплантації понятійного матеріалу з гендеру на стать. Бінарне визначення статі не влаштовує сучасних лівих лібералів. Вони намагаються продемонструвати, що небінарність гендеру вкорінена в небірнарності статі. Саме в цьому, на наше міркування, криється їхня пильна увага до інтерсексів, адже останніх пропонують розуміти як свідчення того, що стать як гендер є спектрами.

Однак, як ми зазначали вище, cmams, на відміну від гендеру, корелюється з бінарним поділом на жіночі $i$ чоловічі гамети. Стать може бути лише бінарною, що не заважає визнанню небінарності гендеру.

Непослідовність національного правового регулювання співвідношення понять «гендер» $\mathbf{i}$ «стать». Слід відзначити тенденцію до все більшого поширення національним законодавством терміно-поняття «гендер». Однак із такими новелами пов'язані i деякі непослідовності, адже не зрозуміло, як ці поняття співіснують у межах єдиного правового поля.

Так, частина 1 статті 1 Закону України «Про забезпечення рівних прав та можливостей жінок і чоловіків» встановлює, що гендерна рівність - це «рівний правовий статус жінок і чоловіків та рівні можливості для його реалізації, що дозволяє особам обох статей брати рівну участь у всіх сферах життєдіяльності суспільства» [18]. Прикметно, що у запропонованій дефініції гендер визначається через стать; чоловік і жінка тут також розуміються саме як протилежні ста$m i$. Погоджуючись із думкою М. Ратушного про те, що означений закон був першою спробою закріпити заборону дискримінації жінок та чоловіків у спеціальному законі (а хіба доводиться багато очікувати від першої спроби?) [19], слід усе ж відзначити певну застарілість використовуваного апарату. Сучасне уявлення про гендер як соціальний конструкт засноване на запереченні біологічного детермінізму в розумінні відносин між статтями.

Закон України «Про Національну раду України 3 питань телебачення і радіомовлення» також говорить саме про гендерний (а не статевий) склад Національної ради; чинна редакція Кодексу законів про працю згадує гендер з-поміж захищених від дискримінації ознак поруч зі статтю (залишаючи гадати, за якою саме ознакою слід квалі- 
фікувати дискримінацію жінок та чоловіків, гендерною чи статевою). Постає запитання: що саме відбувається в законодавстві України? Можливо, перед нами всього лише зміна вивісок, де застаріле слово «стать» услід за модою поступається більи прогресивному аналогу, чи ми насправді спостерігаємо за початком гендерної революиіи в Україні? Залежно від особистих побажань i настроїв на ці питання можна дати протилежні відповіді, і жодна 3 них не буде відповідати об'єктивній дійсності, оскільки об'єктивно 3 цього питання існує невизначеність, що, до слова, звичайно ж створена умисно, для того щоб національні політичні агенти мали більше простору для геополітичних маневрів з питань гендерної рівності.

Чи не найбільш проблематичною і непослідовною в цьому стосунку можна вважати чинну систему ідентифікації громадян України, у якій враховується не гендер, а саме стать.

Так, згідно з п. 8 Правил державної реєстрації актів цивільного стану в Україні, затверджених Наказом Міністерства юстиції України від 18.10.200 № 52/5, заява про державну реєстрацію народження має містити поруч 3 іншими відомостями про дитину вказівку на ї стать [21]. Аналогічно, згідно 3 Тимчасовим порядком оформлення і видачі паспорта громадянина України стать вказується у шостому рядку паспорта громадянина України [22].

\section{Деякі узагальнення}

Непослідовність позиції законодавця стосовно співвідношення статі і гендеру вбачається нам у наступному. Визнання гендеру свідчить про визнання державою тієї обставини, що більшість відмінностей між чоловіками і жінками мають радше соціальний, ніж біологічний характер, саме тому для формування ідентичності особи гендер має важливіше значення, ніж стать. За таких умов статева диференціація у вітчизняному законодавстві виглядає як атавізм.

Вітчизняний законодавець відкрито поклоняється двом богам, намагаючись догодити як противникам, так і послідовникам гендерної ідеології. Це, зі свого боку, спричиняє більш ніж просто термінологічні не- узгодженості. Так, виглядає незрозумілим становище, за якого батьки зобов'язані зробити вибір стосовно статі виховання при реєстрації народження дитини з порушенням статевої диференціації - у цій частині, на нашу думку, більше віталася 6 гнучкість правового регулювання. Однак парадокс цієї ситуації в тім, що, визнаючи гендер, та, вочевидь, елементи гендерної ідеології, законодавець, між тим, продовжує розглядати саме диференціацію на статі як фундаментальну для ідентифікації особи.

Гадаємо, що найкращою відповіддю на означені вище вади правового регулювання була б системна уніфікація використання терміно-понять «стать» та «гендер». При цьому слід чітко уявляти, у яких випадках диференціація повинна носити статевий, а в яких - гендерний зміст.

\section{Мiтература}

1. Кубі Г. Глобальна сексуальна революція: руйнування свободи в ім'я свободи. К.: Мандрівець, 2018, 328 с.

2. Millennium Development Goals : [URL: https:/www.un.org/development/desa/ ru/millennium-development-goals.html]

3. Әсэсовец и вопрос крови. Биологические основы и их осмысленное применение для сохранения и приумножения нордической крови, [пер. с нем.], М.: Русская правда, 2000, 55 с.

4. The U.S. Will Add A 3rd Gender Option On Passports : [URL: https://www. npr.org/2021/06/30/1011866915/u-s-will-addan-option-other-than-male-or-female-onpassports]

5. Turkey's withdrawal from the Istanbul Convention: A retrogressive step back in the protection of women's human rights enshrined in the CEDAW Convention : [URL: https://reliefweb.int/report/turkey/turkey-swithdrawal-istanbul-convention-retrogressive-step-back-protection-women-s]

6. Шевчук Т.I. Молекулярно-генетичні механізми і рівні визначення статі у людини та їх порушення / Хлєстова С.С., Горбатюк С.М., Васенко Т.Б., Спрут О.В. Вісник Вінницького національного медичного університету, 2019, Т. 23, №4, с. 717 722. 
7. Soh Debra. The End of Gender: Debunking the Myths about Sex and Identity in Our Society Simon and Schuster, 2020, $336 \mathrm{p}$

8. Integrating the gender perspective into the work of United Nations human rights treaty bodies. Report by the SecretaryGeneral. Geneva, 14-18 September 1998, $18 \mathrm{p}$.

9. Office of the Special Adviser on Gender Issues and the Advancement of Women, United Nations. Important Concepts Underlying Gender Mainstreaming : [URL: https://www. un.org/womenwatch/osagi/pdf/factsheet2.pdf]

10. The Yogyakarta Principles plus 10 $(\mathrm{YP}+10)$ : [URL: http://yogyakartaprinciples.org/]

11. Evaluation of OHCHR Performance in Gender Mainstreaming (2010)

12. 2021 ICD-10-CM Codes : [URL : https://www.icd10data.com/ICD10CM/Codes]

13. Медико-біологічні та соціальнопсихологічні показання для зміни (корекції) статевої належності. Наказ Міністерства охорони здоров'я України 05.10.2016№ 1041 : [URL : https://zakon.rada.gov.ua/ laws/show/z1589-16\#n17]

14. Уніфікований клінічний протокол медичної допомоги «гендерна дисфоpiя» : [URL : https://www.insight-ukraine.org/ uploads/files/clinic_protokol.pdf]

15. Kupers, Terry A. Toxic masculinity as a barrier to mental health treatment in prison. Journal of Clinical Psychology (Wiley) 61 (6): 713-724.

16. Здравомыслова Е.А., Темкина А.А. Социальное конструирование гендера, Социологический журнал, 1998, №3/4, С. 111 122.

17. Here's What to Know About Having a Baby Who Is Intersex : [URL : https://www. healthline.com/health/baby/what-does-intersex-look-like]

18. Закону України «Про забезпечення рівних прав та можливостей жінок і чоловіків», Відомості Верховної Ради України (ВBP), 2005, № 52, ст.561

19. Ратушний М. Гендер в Україні: юридичний аналіз і рекомендації для ЗМІ : [URL : https://imi.org.ua/articles/hender-vukrajini-yurydychnyj-analiz-i-rekomendatsijidlya-zmi-i882]
20. Закон України «Про Національну раду України з питань телебачення і радіомовлення», Відомості Верховної Ради України (ВВР), 1997, № 48, ст. 296

21. Правила державної реєстрації актів цивільного стану в Україні, затверджені наказом Міністерства юстиції України від 18.10 .2000 № 52/5

22. Тимчасовий порядок оформлення і видачі паспорта громадянина України, затверджений наказом Міністерства внутрішніх справ України 06.06.2019 № 456

\section{LEGAL REGULATION OF SEX IDEN- TIFICATION AGAINST THE BACK- GROUND OF GENDER EQUITY POLICY}

The article discusses a number of issues related to its main topic - the legal regulation of gender determination. The leading object of criticism is the thesis that sex is not binary, but rather a spectrum. In this way, representatives of gender studies try to demonstrate that the non-binary nature of gender is rooted in the non-binary nature of gender. This, in our opinion, is their close attention to intersex, because the latter are offered to be understood as evidence that gender and gender are spectra. Emphasis is placed on the fallacy of such a conceptual transplant, because sex is determined not by the presence of genitals, and gametes, which are exclusively of two types - either female or male. The author concludes that the use of the term "gender" in the national field indicates the state's recognition of the fact that most differences between men and women are social rather than biological, which is why gender is more important than gender for the formation of personal identity. Under such conditions, gender differentiation in domestic law looks like an atavism. It is concluded that it is necessary to unify the use of the terms "sex" and "gender". At the same time, however, it should be clearly imagined in which cases the differentiation should have a sexual and in which a gender content.

It should be noted that the term "gender" is becoming more widespread in national legislation. However, there are some inconsistencies associated with such short stories, as it is unclear how these concepts coexist within a 


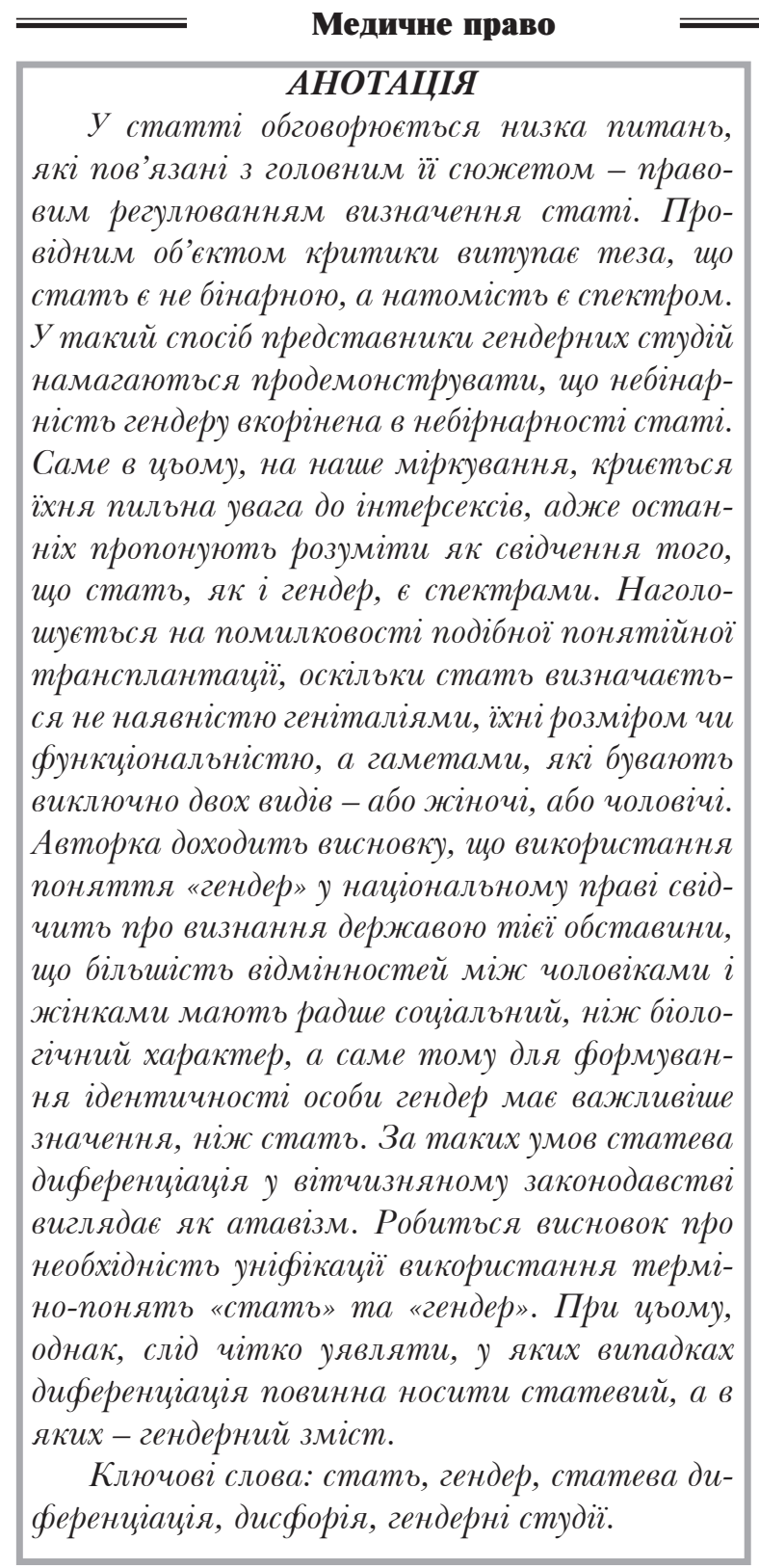

single legal field.

The question arises: what exactly is happening in the legislation of Ukraine? Maybe we are just changing the signs, where the outdated word "sex" follows the fashion of a more progressive counterpart, or are we really watching the beginning of the gender revolution in Ukraine? Depending on personal wishes and attitudes, these questions can be answered in the opposite way, and none of them will correspond to the objective reality, because objectively there is uncertainty on this issue, which, incidentally, is of course created intentionally to national political agents had more room for geopolitical maneuvers on gender equality.

Perhaps the most problematic and inconsistent in this regard is the current system of identification of Ukrainian citizens, which does not take into account gender, but gender.

Thus, according to paragraph 8 of the Rules of state registration of civil status in Ukraine, approved by the Order of the Ministry of Justice of Ukraine from 18.10.200 № $52 / 5$, the application for state registration of birth must contain, among other information about the child, an indication of his sex. Similarly, in accordance with the Temporary Procedure for Registration and Issuance of a Passport of a Citizen of Ukraine, gender is indicated in the sixth line of the passport of a citizen of Ukraine.

Key words: sex, gender, sexual differentiation, dysphoria, gender studies. 